\title{
Effects of feeding different linseed sources on omasal fatty acid flows and fatty acid profiles of plasma and milk fat in lactating dairy cows
}

\author{
A. Sterk, ${ }^{\star} \dagger^{1}$ B. Vlaeminck, $\ddagger$ A. M. van Vuuren, ${ }^{\star} \S$ W. H. Hendriks, ${ }^{*} \#$ and J. Dijkstra ${ }^{\star}$ \\ *Animal Nutrition Group, Wageningen University, De Elst 1, 6708 WD Wageningen, the Netherlands \\ †Agrifirm Innovation Center, Boogschutterstraat 1A, 7302 HA Apeldoorn, the Netherlands \\ łLaboratory for Animal Nutrition and Animal Product Quality, Ghent University, Proefhoevestraat 10, 9090 Melle, Belgium \\ §Wageningen UR Livestock Research, Edelhertweg 15, 8219 PH Lelystad, the Netherlands \\ \#Faculty of Veterinary Medicine, Utrecht University, Yalelaan 1, 3584 CL Utrecht, the Netherlands
}

\begin{abstract}
The aim of this experiment was to study the effects of feeding different linseed sources on omasal fatty acid (FA) flows, and plasma and milk FA profiles in dairy cows. Four ruminally cannulated lactating HolsteinFriesian cows were assigned to 4 dietary treatments in a $4 \times 4$ Latin square design. Dietary treatments consisted of supplementing crushed linseed (CL), extruded whole linseed (EL), formaldehyde-treated linseed oil (FL) and linseed oil in combination with marine algae rich in docosahexaenoic acid (DL). Each period in the Latin square design lasted $21 \mathrm{~d}$, with the first $16 \mathrm{~d}$ for adaptation. Omasal flow was estimated by the omasal sampling technique using Cr-EDTA, Yb-acetate, and acid detergent lignin as digesta flow markers. The average DM intake was $20.6 \pm 2.5 \mathrm{~kg} / \mathrm{d}, \mathrm{C} 18: 3 \mathrm{n}-3$ intake was $341 \pm 51 \mathrm{~g} / \mathrm{d}$, and milk yield was $32.0 \pm 4.6 \mathrm{~kg} / \mathrm{d}$. Milk fat yield was lower for the DL treatment $(0.96$ $\mathrm{kg} / \mathrm{d}$ ) compared with the other linseed treatments (CL, $1.36 \mathrm{~kg} / \mathrm{d} ; \mathrm{EL}, 1.49 \mathrm{~kg} / \mathrm{d} ; \mathrm{FL}, 1.54 \mathrm{~kg} / \mathrm{d}$ ). Omasal flow of C18:3n-3 was higher and C18:3n-3 biohydrogenation was lower for the EL treatment $(33.8 \mathrm{~g} / \mathrm{d} ; 90.9 \%) \mathrm{com}$ pared with the CL $(21.8 \mathrm{~g} / \mathrm{d} ; 94.0 \%)$, FL $(15.5 \mathrm{~g} / \mathrm{d}$; $95.4 \%)$, and DL $(4.6 \mathrm{~g} / \mathrm{d} ; 98.5 \%)$ treatments, whereas whole-tract digestibility of crude fat was lower for the EL treatment (64.8\%) compared with the CL (71.3\%), FL (78.5\%), and DL (80.4\%) treatments. The proportion of C18:3n-3 (g/100 g of FA) was higher for the FL treatment compared with the other treatments in plasma triacylglycerols (FL, 3.60; CL, 1.22; EL, 1.35; DL, 1.12) and milk fat (FL, 3.19; CL, 0.87; EL, 0.83; DL, 0.46). Omasal flow and proportion of C18:0 in plasma and milk fat were lower, whereas omasal flow and proportions of biohydrogenation intermediates in plasma and milk fat were higher for the DL treatment compared with the other linseed treatments. The results
\end{abstract}

Received April 22, 2011.

Accepted February 5, 2012.

${ }^{1}$ Corresponding author: a.sterk@agrifirm.com demonstrate that feeding EL did not result in a higher C18:3n-3 proportion in plasma and milk fat despite the higher omasal C18:3n-3 flow. This was related to the decreased total-tract digestibility of crude fat. Feeding FL resulted in a higher C18:3n-3 proportion in plasma and milk fat, although the omasal C18:3n-3 flow was similar or lower than for the CL and EL treatment, respectively. Feeding DL inhibited biohydrogenation of trans-11,cis-15-C18:2 to C18:0, as indicated by the increased omasal flows and proportions of biohydrogenation intermediates in plasma and milk fat.

Key words: biohydrogenation, linseed, docosahexaenoic acid, fatty acid

\section{INTRODUCTION}

The FA composition of milk fat depends on various dietary characteristics including roughage-to-concentrate ratio (Sterk et al., 2011), FA intake, FA metabolism in the rumen (Jenkins et al., 2008), lipid mobilization, and FA metabolism in the mammary gland (Chilliard et al., 2007). Major dietary sources of linolenic acid (cis9,cis-12,cis-15-C18:3; C18:3n-3) include grass (>60\% of FA) and linseed ( $>50 \%$ of FA), and diets that contain these sources have a relatively high proportion of C18:3n-3. The proportion of C18:3n-3 in milk fat, however, is generally low ( $<1 \%$ of FA; Heck et al., 2009), because in the rumen, dietary lipids undergo extensive transformations by ruminal microorganisms in 2 major processes; lipolysis and biohydrogenation. Consequently, in ruminants, marked differences exist between the FA profile in the diet (mainly unsaturated FA) and the FA profile in duodenal digesta (mainly saturated FA; Jenkins et al., 2008). To overcome these ruminal transformations, protection technologies have been developed, which aim to prevent ruminal FA metabolism or ensure the accumulation of specific biohydrogenation intermediates (Fievez et al., 2007). Protection of linseed with formaldehyde treatment can increase the proportion of $\mathrm{C} 18: 3 \mathrm{n}-3$ in milk fat up to $6.4 \%$ of total FA (Goodridge et al., 2001). Effective formaldehyde 
treatment requires pretreatment of linseed to allow the formation of cross-links between formaldehyde and protein (Fievez et al., 2007). When C18:3n-3 was directly infused in the abomasum (Petit et al., 2002) or duodenum (Khas-Erdene et al., 2010), the proportion of C18:3n-3 in milk fat increased up to 13.9 or $25.4 \%$ of total FA, respectively. Extrusion of whole linseed resulted in a decrease in C18:3n-3 biohydrogenation in vitro (Sterk et al., 2010). However, postruminal C18:3n-3 digestibility from extruded whole linseed could be low due to the presence of intact seed hulls protecting the seed contents in the extruded product. The accumulation of biohydrogenation intermediates from C18:3n-3 biohydrogenation of linseed oil can be influenced by the addition of docosahexaenoic acid (C22:6n-3; DHA), as demonstrated in vitro (Sterk et al., 2010), although no in vivo studies have been conducted to determine effects on plasma and milk FA profiles of DHA added to diets containing linseed or linseed oil.

A previous in vitro study evaluating several chemically or technologically treated linseed products indicated that formaldehyde-treated crushed linseed and extruded whole linseed decreased ruminal biohydrogenation of C18:3n-3 (Sterk et al., 2010). Because of a possible overestimation of protected $\mathrm{C} 18: 3 \mathrm{n}-3$ in vitro (Fievez et al., 2007), the true rumen inertness and transfer efficiency from feed to milk should be determined in vivo. To our knowledge, a comparison of flows of C18:3n-3 from the rumen with crushed linseed, extruded whole linseed, formaldehyde-treated linseed oil, and linseed oil in combination with DHA has not been reported. The objective of this study was, therefore, to determine the effects of feeding crushed linseed, extruded whole linseed, formaldehyde-treated linseed oil, and linseed oil in combination with DHA addition on FA flows through the gastrointestinal tract and on plasma and milk FA profiles of lactating dairy cows. Crushed linseed was included in the study to be able to compare the effects of the different treated linseed sources with an unprotected linseed source.

\section{MATERIALS AND METHODS}

\section{Experimental Design, Animals, and Housing}

All experimental procedures were approved by the Institutional Animal Care and Use Committee of Wageningen University (Wageningen, the Netherlands) and carried out under the Dutch Law on Animal Experimentation. Four lactating multiparous HolsteinFriesian dairy cows $(625 \pm 69 \mathrm{~kg}$ of BW; $52 \pm 22 \mathrm{DIM}$; values expressed as means $\pm \mathrm{SD}$ ) fitted with a ruminal cannula (10 cm i.d.; Bar Diamond Inc., Parma, ID) were fed different linseed diets according to a $4 \times 4$ Latin square design. Each period in the Latin square design lasted $21 \mathrm{~d}$ with the first $16 \mathrm{~d}$ for adaptation. Cows were housed in individual tie-stalls with continuous access to water and milked twice daily at 0630 and $1700 \mathrm{~h}$.

\section{Diets}

The 4 dietary treatments consisted of a basal diet with the addition of crushed linseed (CL), extruded whole linseed (EL), formaldehyde-treated linseed oil (FL), or DHA in combination with linseed oil (DL). The ingredient and chemical composition of the 4 diets are presented in Tables 1 and 2, respectively. The diets were designed to provide equal amounts of C18:3n-3. Crushed linseed was prepared in a roller mill $(0.25$ mm; Ipswich Turner, Christy Turner Ltd., Ipswich, UK). Extruded whole linseed was prepared as a mixture of whole linseed and wheat bran (70:30 vol/vol linseed:wheat bran) in a small-scale single-screw extruder line of Almex AL150 (Almex BV, Zutphen, the Netherlands) equipped with a pellet press of Robinson/ Heesen V2/30 (Heesen, Boxtel, the Netherlands) and cooler unit $\left(6 \%\right.$ steam and $2 \%$ water, $127^{\circ} \mathrm{C}$ for $20-30$ s). Formaldehyde-treated linseed oil was prepared by homogenizing Na-casein and linseed oil (35:65 vol/vol Na-casein:linseed oil) and spray drying the emulsion in a conventional spray dryer with a nozzle atomizer (spray dryer P12.5; GEA Niro, Soeborg, Denmark) and an external fluid bed. The spray-dried emulsion was then treated with $0.65 \%$ formalin ( $37 \%$ formaldehyde). The DHA was supplemented as a concentrate containing 11\% DHA (product basis; DHA Gold; Martek Biosciences Corp., Columbia, MD) and the linseed oil was provided as such. To prevent variation in feed intake and C18:3n-3 intake, diets were offered at $95 \%$ of ad libitum intake, which was determined during the first $7 \mathrm{~d}$ of the first experimental period. The diets were offered as 2 equal meals at 0615 and $1645 \mathrm{~h}$. The concentrates and linseed products were thoroughly mixed with the basal diet just before feeding.

\section{Measurements and Sampling}

Feed intake measurements determined from d 15 to d 20 of each experimental period were used to calculate average nutrient intake per cow per period. All ration ingredients were sampled once weekly and pooled per period. The pooled samples of grass and corn silage were stored at $-20^{\circ} \mathrm{C}$, freeze dried, and ground to pass through a 1-mm sieve before analysis. The pooled samples of the concentrates and linseed products were 
Table 1. Ingredient composition ( $\mathrm{g} / \mathrm{kg}$ of DM; DM basis) of the diets supplemented with crushed linseed (CL), extruded whole linseed (EL), formaldehyde-treated linseed oil (FL), and docosahexaenoic acid (DHA) addition to linseed oil (DL)

\begin{tabular}{|c|c|c|c|c|}
\hline \multirow[b]{2}{*}{ Composition } & \multicolumn{4}{|c|}{ Dietary treatment } \\
\hline & CL & EL & FL & $\mathrm{DL}$ \\
\hline Grass silage $^{1}$ & 312 & 310 & 312 & 312 \\
\hline Corn silage $^{2}$ & 294 & 292 & 294 & 294 \\
\hline Wheat & 68 & 64 & 73 & 77 \\
\hline Rapeseed meal & 65 & 61 & 69 & 69 \\
\hline Soybean meal & 49 & 47 & 50 & 49 \\
\hline Corn & 52 & 45 & 60 & 54 \\
\hline Palm kernel expeller & 22 & 19 & 25 & 22 \\
\hline Soybean hulls & 21 & 18 & 24 & 22 \\
\hline Rapeseed expeller & 16 & 14 & 18 & 16 \\
\hline Beet pulp & 11 & 9 & 12 & 22 \\
\hline Molasses & 13 & 11 & 15 & 16 \\
\hline Rapeseed meal, formaldehyde-treated & 8 & 7 & 9 & 8 \\
\hline Corn gluten feed & - & - & - & 4 \\
\hline Toasted soybean expeller & - & - & - & 2 \\
\hline Soybean meal, formaldehyde-treated & - & - & - & 2 \\
\hline Premix $^{3}$ & 2 & 1 & 2 & 2 \\
\hline Limestone & 2 & 1 & 2 & 2 \\
\hline Salt & 1 & 1 & 1 & 1 \\
\hline Palm oil & 1 & 1 & 1 & 1 \\
\hline CL & 65 & - & - & - \\
\hline EL & - & 99 & - & - \\
\hline FL & - & - & 33 & - \\
\hline Linseed oil & - & - & - & 21 \\
\hline DHA Gold ${ }^{4}$ & - & - & - & 4 \\
\hline
\end{tabular}

${ }^{1}$ Grass silage, g/kg of DM: 439 DM (fresh weight basis), 89 crude ash, 188 CP, 33 crude fat, 530 NDF, 34 sugar, 75 intestinal digestible protein (DVE; Tamminga et al., 1994), 6.07 MJ of $\mathrm{NE}_{\mathrm{L}}, 18.5$ total FA, 0.2 C12:0, 0.2 C14:0, 3.4 C16:0, 0.5 C16:1, 0.3 C18:0, 0.6 cis-9-C18:1, 3.2 cis-9, cis-12-C18:2, and 10.1 cis-9, cis-12, cis-15-C18:3. ${ }^{2}$ Corn silage, g/kg of DM: 328 DM (fresh weight basis), 46 crude ash, 64 CP, 29 crude fat, 399 NDF, 340 starch, 45 DVE, 6.69 MJ of $\mathrm{NE}_{\mathrm{L}}, 19.3$ total FA, 0.03 C12:0, 0.03 C14:0, 3.1 C16:0, 0.5 C18:0, 4.2 cis-9-C18:1, 10.5 cis-9,cis-12-C18:2, and 0.9 cis-9, cis-12,cis-15-C18:3.

${ }^{3}$ Contained per kilogram of mix: $93 \mathrm{~g}$ of $\mathrm{Ca}, 400 \mathrm{~g}$ of $\mathrm{Mg}, 5 \mathrm{mg}$ of $\mathrm{S}, 4 \mathrm{~g}$ of $\mathrm{Cu}, 3.3 \mathrm{~g}$ of $\mathrm{Mg}, 322 \mathrm{mg}$ of I, 97 $\mathrm{mg}$ of $\mathrm{Co}, 80 \mathrm{mg}$ of Se, 2,600,000 IU of vitamin A, 580,000 IU of vitamin E (Premix 2033; Pre-Mervo UA, Utrecht, the Netherlands).

${ }^{4}$ Martek Biosciences Corp., Columbia, MD.

ground to pass through a $1-\mathrm{mm}$ sieve and stored at $4^{\circ} \mathrm{C}$ pending analysis.

The digesta flow into the omasum was assessed by the triple marker method (France and Siddons, 1986) using Cr-EDTA, Yb-acetate, and ADL as indigestible markers for liquid, small particle, and large particle phases, respectively. The Cr-EDTA was prepared using standard procedures (Binnerts et al., 1968) and Ybacetate was obtained from a commercial source (Dasico A/S, Birkerød, Denmark). Acid detergent lignin was used as an internal marker naturally present in the diet (Table 2). Starting at d 15, Cr-EDTA (3.0 g Cr/d) and $\mathrm{Yb}$-acetate $(1.7 \mathrm{~g} \mathrm{Yb} / \mathrm{d})$ were dissolved in $2 \mathrm{~L}$ of distilled water and infused via separate lines into the rumen at a constant rate $(83 \mathrm{~mL} / \mathrm{h})$ using a peristaltic pump (Isco WIZ Peristaltic Pump Diluter Dispenser; ISCO Inc., Lincoln, NE). Infusions of Cr-EDTA and Yb-acetate started with primer doses of 4.5 and $2.6 \mathrm{~g}$ of $\mathrm{Cr}$ and $\mathrm{Yb}$, respectively. These primer doses were used to reach a rapid equilibrium of the ruminal marker concentrations. Marker infusions were stopped on d 19 after the last digesta sample was taken.

Samples $(775 \mathrm{~g})$ of digesta flowing into the omasal canal were collected 3 times daily at 4 -h intervals on $d$ 18 and 19 using the omasal sampling device (Huhtanen et al., 1997) with modifications (Ahvenjärvi et al., 2000). In addition, the sampling device was adjusted by adding a rugby ball shaped device with 13 openings ( $8 \mathrm{~mm}$ i.d.) to the tube orifice to prevent the tube from being blocked by coarse digesta. The sampling device was installed in the omasum at d 15 at the same time when marker infusions were started. At some sampling points the openings of the sampling device needed to be manually unblocked as described by Brito et al. (2007). Over the 2 sampling days, a total of 6 samples per cow were taken, with the first sample at $1200 \mathrm{~h}$ and the last sample at $2200 \mathrm{~h}$, thereby covering a $12-\mathrm{h}$ period, which was considered representative for an en- 
Table 2. Chemical and FA composition of the diets supplemented with crushed linseed (CL), extruded whole linseed (EL), formaldehyde-treated linseed oil (FL), and docosahexaenoic acid addition to linseed oil (DL)

\begin{tabular}{|c|c|c|c|c|}
\hline \multirow[b]{2}{*}{ Composition } & \multicolumn{4}{|c|}{ Dietary treatment } \\
\hline & CL & EL & $\mathrm{FL}$ & DL \\
\hline $\mathrm{DM}, \mathrm{g} / \mathrm{kg}$ & 583 & 589 & 583 & 582 \\
\hline \multicolumn{5}{|l|}{ Nutrient, $\mathrm{g} / \mathrm{kg}$ of DM } \\
\hline $\mathrm{CP}$ & 170 & 171 & 171 & 163 \\
\hline Crude fat & 62 & 65 & 55 & 56 \\
\hline NDF & 360 & 361 & 354 & 354 \\
\hline $\mathrm{ADF}$ & 216 & 215 & 213 & 212 \\
\hline ADL & 32 & 32 & 31 & 31 \\
\hline Starch & 148 & 147 & 152 & 153 \\
\hline Sugar & 38 & 38 & 39 & 40 \\
\hline Crude ash & 68 & 67 & 69 & 69 \\
\hline $\mathrm{DVE}^{1}$ & 84 & 83 & 90 & 87 \\
\hline $\mathrm{NE}_{\mathrm{J}}{ }^{2} \mathrm{MJ} / \mathrm{kg}$ of $\mathrm{DM}$ & 7.14 & 7.09 & 7.20 & 7.23 \\
\hline \multicolumn{5}{|l|}{$\mathrm{FA}, \mathrm{g} / \mathrm{kg}$ of $\mathrm{DM}$} \\
\hline Total FA & 45.4 & 46.3 & 44.5 & 44.3 \\
\hline C12:0 & 1.15 & 1.0 & 1.5 & 1.2 \\
\hline C14:0 & 0.4 & 0.4 & 0.6 & 0.7 \\
\hline $\mathrm{C} 16: 0$ & 4.5 & 4.6 & 4.7 & 5.1 \\
\hline C16:1 & 0.2 & 0.2 & 0.2 & 0.2 \\
\hline C18:0 & 1.3 & 1.4 & 1.0 & 1.2 \\
\hline cis-9-C18:1 & 8.8 & 8.9 & 9.0 & 8.5 \\
\hline cis-9,cis-12-C18:2 & 11.8 & 12.0 & 11.9 & 11.6 \\
\hline cis-9,cis-12,cis-15-C18:3 & 17.3 & 17.9 & 15.7 & 15.2 \\
\hline $\mathrm{C} 22: 6 \mathrm{n}-3$ & $\mathrm{ND}^{3}$ & ND & $\mathrm{ND}$ & 0.6 \\
\hline $\mathrm{UFA}^{4}$ & 38.0 & 39.0 & 36.8 & 36.1 \\
\hline
\end{tabular}

${ }^{1}$ Intestinal digestible protein (Tamminga et al., 1994).

${ }^{2}$ Net energy for lactation calculated with the VEM system (Van Es, 1975).

${ }^{3} \mathrm{ND}=$ not detectable.

${ }^{4}$ Unsaturated FA $=\Sigma($ cis-9-C16:1, cis-9-C18:1, cis-9, cis-12-C18:2, cis-9, cis-12,cis-15-C18:3, C22:6n-3).

tire feeding cycle. Subsamples for VFA and ammonia-N analysis were immediately taken from each sample and stabilized with phosphoric acid (VFA analysis) and trichloroacetic acid (ammonia-N sample) as described by Taweel et al. (2005). Samples were immediately stored at $-20^{\circ} \mathrm{C}$ after sampling pending analysis. After the collection period, digesta samples were thawed at room temperature, pooled, and separated into large particle, small particle, and liquid fractions by filtration and centrifugation at $10,000 \times g$ for 15 min at $4^{\circ} \mathrm{C}$ (Ahvenjärvi et al., 2000). Each fraction was freeze dried and stored at $4^{\circ} \mathrm{C}$ pending analysis. The large particle fraction was ground to pass a 1-mm sieve before analysis. The relative proportions of the fluid, small particle, and large particle fractions in true digesta were reconstituted using the marker concentrations in the different fractions (France and Siddons, 1986).

Feces were quantitatively collected for a total of 60 $\mathrm{h}$, starting at $1200 \mathrm{~h}$ on $\mathrm{d} 16$ and finishing at $0000 \mathrm{~h}$ on d 19. Every $8 \mathrm{~h}$, the excreted feces were weighed, thoroughly mixed, and sampled (5\%,wt/wt). Samples were stored at $-20^{\circ} \mathrm{C}$, then freeze dried, ground $(1 \mathrm{~mm})$, pooled, and stored at $4^{\circ} \mathrm{C}$ pending analysis.
Milk yield was recorded from d 15 to 20 of each experimental period. Milk samples were collected from each cow over 2 consecutive milkings (d 17 p.m. and d 18 a.m.) during each experimental period. Pooled milk samples (equal volume) per cow per period were stored pending analysis for fat, protein, lactose, MUN, and SCC. A second set of milk samples was taken on the same days during each experimental period and immediately stored at $-20^{\circ} \mathrm{C}$ pending $\mathrm{FA}$ analysis. These samples were pooled per cow per period (equal volume) during the FA analysis.

Blood samples from the coccygeal vein were obtained with heparinized Vacutainer tubes (Becton Dickinson, Breda, the Netherlands) at $0900 \mathrm{~h}$ on d 17 of each experimental period. Blood was centrifuged at 3,000 $\times g$ for $15 \mathrm{~min}$ and plasma was collected and stored at $-80^{\circ} \mathrm{C}$ until analysis of $\mathrm{FA}$ in the triacylglycerol (TAG) fraction.

\section{Analytical Procedures}

The composite samples of the silages, concentrates, and linseed products were analyzed for DM, ash, N, 
crude fat, starch, sugars, NDF, ADF, ADL, and FA methyl esters (FAME). Liquid, small particle, and large particle fractions were analyzed for DM, ash, N, crude fat, FAME, and marker concentrations $(\mathrm{Cr}$ and $\mathrm{Yb})$. Additionally, in the small and large particle fractions, NDF and ADL were measured, whereas in the liquid fraction, VFA and ammonia-N concentrations were determined. Fecal samples were analyzed for DM, crude fat, and marker concentrations $(\mathrm{Cr}, \mathrm{Yb}$, and ADL).

Dry matter, ash, N, crude fat, starch, sugars, NDF, $\mathrm{ADF}$, and ADL were analyzed as described by Abrahamse et al. (2008a,b). The $\mathrm{Cr}$ concentration was determined by carbonization at $550^{\circ} \mathrm{C}$, followed by combustion at $550^{\circ} \mathrm{C}$. The $\mathrm{Cr}_{2} \mathrm{O}_{3}$ was then solubilized by oxidizing $\mathrm{Cr}$ (III) to $\mathrm{Cr}(\mathrm{VI})$ by potassium bromate in a phosphoric acid manganese solution. After dilution, $\mathrm{Cr}(\mathrm{VI})$ was measured by inductively coupled plasmaatomic emission spectrometry (ICP-AES; Perkin Elmer Optima 3300 DV ICP; PerkinElmer, Groningen, the Netherlands). The $\mathrm{Yb}$ concentration was determined by carbonization at $550^{\circ} \mathrm{C}$, followed by combustion at $550^{\circ} \mathrm{C}$. The ash was then destructed in diluted nitric acid and, subsequently, $\mathrm{Yb}$ measured by ICP-AES. The concentration of VFA was determined using GC (GC type Fisons HRGC MEGA2; Fisons Instruments, Milano, Italy) as described by Taweel et al. (2005). Ammonia-N concentration was determined by spectrophotometry using the Berthelot reaction as described by Taweel et al. (2005). Analysis of fat, protein, lactose, MUN, and SCC in milk samples was carried out as described by van Zijderveld et al. (2011).

Fatty acids in feed and omasal samples were determined as described by Khan et al. (2009). Briefly, FA in $375 \mathrm{mg}$ of feed and omasal samples were extracted with $15 \mathrm{~mL}$ of chloroform-methanol (2:1 vol/vol) according to Folch et al. (1957). Internal standard (C13:0) was added to the chloroform-methanol mixture (3 $\mathrm{mg}$ of C13:0/20 mL of chloroform-methanol). Fatty acids were methylated with $0.5 \mathrm{~N} \mathrm{NaOH}$ methanolate, followed by $1.25 \mathrm{~N}$ HCL in methanol, and collected in hexane. Hexane was then evaporated and the FAME were resuspended in $1 \mathrm{~mL}$ of hexane and transferred to GC vials. For milk FA analysis, total lipids were extracted with diethyl ether and petroleum ether according to the Rose-Gottlieb method (AOAC, 1990). Fatty acids from milk lipids were methylated with 2.0 $N$ methanolic $\mathrm{NaOCH}_{3}$, neutralized with $\mathrm{NaHSO}_{4}$, and dried with $\mathrm{Na}_{2} \mathrm{SO}_{4}$. Fatty acid methyl esters were recovered in $1 \mathrm{~mL}$ of hexane. For plasma FA, plasma lipids were extracted with n-octane. The TAG fraction was separated with silica columns (Bond Elut SI, $500 \mathrm{mg}$, $3 \mathrm{~mL}$; Varian Inc., Walnut Creek, CA) rinsed with a mixture of hexane with methyl-t-butyl-ether (96:4 vol/ vol). The solvent of the TAG fraction was evaporated and FA were methylated with $0.4 \mathrm{~mL} 0.5 \mathrm{~N}$ methanolic $\mathrm{NaOCH}_{3}\left(80^{\circ} \mathrm{C}\right.$ for $\left.10 \mathrm{~min}\right)$, followed by $0.5 \mathrm{~mL}$ of $14 \%$ boron trifluoride $\left(80^{\circ} \mathrm{C}\right.$ for $\left.2 \mathrm{~min}\right)$. Fatty acid methyl esters were recovered in $100 \mu \mathrm{L}$ of hexane containing 25 $\mu \mathrm{g}$ of butyl-hydroxy-toluene to prevent oxidation.

The FAME were quantified using GC (Trace GC Ultra; Thermo Fisher Scientific, Waltham MA) with a fused silica capillary column $(100 \mathrm{~m} \times 0.250 \mathrm{~mm}$ and $0.2-\mu \mathrm{m}$ film thickness; SP2560; Supelco Inc., Bellefonte PA). For feed, omasal, and milk samples, the carrier gas was helium at a constant flow of $1.5 \mathrm{~mL} / \mathrm{min}$. For plasma TAG samples, hydrogen was used as the carrier gas at a constant flow of $1.5 \mathrm{~mL} / \mathrm{min}$. The flame ionization detector was set at $280^{\circ} \mathrm{C}$. The time-temperature program used started with an initial temperature of $70^{\circ} \mathrm{C}$ for $4 \mathrm{~min}$, increased at a rate of $1^{\circ} \mathrm{C} / \mathrm{min}$ to $165^{\circ} \mathrm{C}$ for $20 \mathrm{~min}$, increased at a rate of $2^{\circ} \mathrm{C} / \mathrm{min}$ to $170^{\circ} \mathrm{C}$ for $10 \mathrm{~min}$, and increased at a rate of $4^{\circ} \mathrm{C} / \mathrm{min}$ to a final temperature of $215^{\circ} \mathrm{C}$ for $20 \mathrm{~min}$. In addition, for the plasma TAG samples, a second time-temperature program was used to separate the $\mathrm{C} 18: 1$ isomers; the initial temperature of $70^{\circ} \mathrm{C}$ for $1 \mathrm{~min}$ was increased at a rate of $5^{\circ} \mathrm{C} / \mathrm{min}$ to $100^{\circ} \mathrm{C}$ for $2 \mathrm{~min}$, increased at a rate of $10^{\circ} \mathrm{C} /$ min to $175^{\circ} \mathrm{C}$ for $40 \mathrm{~min}$, and then increased at a rate of $10^{\circ} \mathrm{C} / \mathrm{min}$ to a final temperature of $215^{\circ} \mathrm{C}$ for $20 \mathrm{~min}$. Fatty acid methyl esters were identified using external standards (S37, Supelco Inc.; odd- and branched-chain FA, trans-11-C18:1, cis-9,trans-11-C18:2, trans-10, cis12-C18:2; Larodan Fine Chemicals AB, Malmö, Sweden). Fatty acids trans-6+7+8-C18:1, trans-10-C18:1, trans-12-C18:1, trans-13+14-C18:1, cis-12-C18:1, cis13-C18:1, cis-14+trans-16-C18:1, cis-15-C18:1, trans11,cis-15-C18:2 were identified according to the elution sequence reported by Loor et al. (2004) and Shingfield et al. (2006).

\section{Statistics}

Nutrient intake, fermentation characteristics of omasal fluid (averaged per cow per period), nutrient flow into the omasum, apparent rumen digestibility, apparent ruminal biohydrogenation, fecal digestibility data, milk yield, milk composition, milk FA profile, plasma TAG FA profile, and transfer efficiencies of C18:3n-3 were analyzed as a Latin square design using the MIXED procedure of SAS version 9.2 (SAS Institute Inc., Cary, NC) according to

$$
Y_{i j k l}=\mu+T_{i}+P_{j}+C_{k}+\varepsilon_{i j k l},
$$

where $Y_{i j k l}$ is the individual observation, $\mu$ is the overall mean, $T_{i}$ is the effect of dietary treatment, $P_{j}$ is the ef- 
fect of experimental period, $C_{k}$ is the effect of cow, and $\varepsilon_{i j k l}$ is the residual error. The effect of cow was treated as a random effect. Significance of treatment effects was declared at $P \leq 0.05$ and trends at $0.05<P<0.10$. Post-hoc analyses were carried out using the Tukey test to test pairwise comparisons. Data are reported as least squares means \pm standard error of the means.

\section{RESULTS}

\section{Intake and Performance}

Although experimental diets were formulated to provide equal amounts of $\mathrm{C} 18: 3 \mathrm{n}-3$, the $\mathrm{C} 18: 3 \mathrm{n}-3$ content of the FL and DL diets was slightly lower than for the CL and EL diets (Table 2). Nutrient intake for the different dietary treatments is presented in Table 3 . The difference in dietary $\mathrm{C} 18: 3 \mathrm{n}-3$ content was reflected in C18:3n-3 intake, which was slightly lower for the FL and DL treatments compared with the CL and EL treatments. The intake of DHA for the DL treatment was $11.6 \mathrm{~g} / \mathrm{d}$.

Milk production was not affected by the different linseed treatments (Table 4). Milk fat concentration and yield were lower for the DL treatment compared with the other treatments. Milk protein concentration was not affected by the linseed treatments; however, milk protein yield tended to be lower for the DL treatment compared with the FL treatment. Milk lactose concentration and yield, MUN, and SCC were not affected by the linseed treatments.

\section{Fermentation Characteristics}

The dietary treatments had no effect on ammonia-N and total VFA concentration in digesta flowing into the omasal canal (Table 5). The fermentation pattern shifted toward propionate in the DL treatment compared with the FL treatment, concomitant with the opposite shift in acetate.

\section{Nutrient Flow into the Omasum}

Flows of DM, OM, CP, NDF, and crude fat into the omasum were not affected by the different dietary treatments (Table 6). Similarly, total FA flow was not affected by the different treatments. Individual FA flows were significantly affected by the linseed treatments. The C18:3n-3 flow was higher for the EL treatment compared with the CL, FL, and DL treatments, whereas the C18:3n-3 flow for the CL and FL treatments was also higher compared with the DL treatment. Total

Table 3. Nutrient intake and FA intake of cows fed diets supplemented with crushed linseed (CL), extruded whole linseed (EL), formaldehyde-treated linseed (FL), and docosahexaenoic acid addition to linseed oil (DL)

\begin{tabular}{|c|c|c|c|c|}
\hline \multirow[b]{2}{*}{ Intake } & \multicolumn{4}{|c|}{ Dietary treatment } \\
\hline & CL & EL & FL & DL \\
\hline \multicolumn{5}{|l|}{ Nutrient intake $(\mathrm{kg} / \mathrm{d})$} \\
\hline DM & 20.4 & 20.7 & 21.6 & 19.8 \\
\hline $\mathrm{OM}$ & 19.0 & 19.4 & 20.1 & 18.4 \\
\hline $\mathrm{CP}$ & 3.47 & 3.54 & 3.70 & 3.23 \\
\hline Crude fat & 1.28 & 1.34 & 1.19 & 1.12 \\
\hline $\mathrm{NDF}$ & 7.32 & 7.48 & 7.63 & 7.02 \\
\hline $\mathrm{ADF}$ & 4.39 & 4.45 & 4.59 & 4.21 \\
\hline $\mathrm{ADL}$ & 0.65 & 0.66 & 0.67 & 0.61 \\
\hline Starch & 3.04 & 3.07 & 3.28 & 3.03 \\
\hline Sugar & 0.74 & 0.77 & 0.84 & 0.80 \\
\hline \multicolumn{5}{|l|}{ FA (g/d) } \\
\hline Total FA & 929.0 & 963.5 & 960.3 & 877.3 \\
\hline C12:0 & 23.5 & 21.0 & 32.7 & 24.0 \\
\hline C14:0 & 8.7 & 7.8 & 12.0 & 14.2 \\
\hline C16:0 & 92.4 & 96.1 & 100.7 & 100.1 \\
\hline C16:1 & 3.8 & 3.8 & 4.3 & 3.9 \\
\hline C18:0 & 27.1 & 28.4 & 20.8 & 23.9 \\
\hline cis-9-C18:1 & 180.4 & 185.8 & 193.8 & 168.8 \\
\hline cis-9,cis-12-C18:2 & 241.4 & 249.0 & 257.5 & 229.4 \\
\hline cis-9,cis-12,cis-15-C18:3 & 351.7 & 371.6 & 338.5 & 301.4 \\
\hline $\mathrm{C} 22: 6 \mathrm{n}-3$ & $\mathrm{ND}^{1}$ & ND & ND & 11.6 \\
\hline $\mathrm{UFA}^{2}$ & 777.3 & 810.2 & 794.0 & 715.1 \\
\hline
\end{tabular}


Table 4. Milk yield and composition from cows fed diets supplemented with crushed linseed (CL), extruded whole linseed (EL), formaldehyde-treated linseed oil (FL), and docosahexaenoic acid addition to linseed oil (DL)

\begin{tabular}{|c|c|c|c|c|c|c|}
\hline \multirow[b]{2}{*}{ Item } & \multicolumn{4}{|c|}{ Dietary treatment } & \multirow[b]{2}{*}{ SEM } & \multirow[b]{2}{*}{$P$-value } \\
\hline & CL & EL & FL & DL & & \\
\hline Milk yield, $\mathrm{kg} / \mathrm{d}$ & 33.1 & 31.4 & 33.7 & 29.7 & 2.41 & 0.40 \\
\hline \multicolumn{7}{|l|}{ Milk lactose } \\
\hline $\mathrm{kg} / \mathrm{d}$ & $\begin{array}{l}4.02 \\
1.53\end{array}$ & $\begin{array}{l}4.02 \\
1.42\end{array}$ & $\begin{array}{l}4.04 \\
1.57\end{array}$ & $\begin{array}{l}4.42 \\
1.31\end{array}$ & $\begin{array}{l}0.016 \\
0.113\end{array}$ & $\begin{array}{l}0.14 \\
0.30\end{array}$ \\
\hline \multicolumn{7}{|l|}{ Milk fat } \\
\hline$\%$ & $4.30^{\mathrm{a}}$ & $4.75^{\mathrm{a}}$ & $4.67^{\mathrm{a}}$ & $3.27^{\mathrm{b}}$ & 0.570 & 0.002 \\
\hline $\mathrm{kg} / \mathrm{d}$ & $1.36^{\mathrm{a}}$ & $1.49^{\mathrm{a}}$ & $1.54^{\mathrm{a}}$ & $0.96^{\mathrm{b}}$ & 0.140 & $<0.001$ \\
\hline \multicolumn{7}{|l|}{ Milk protein } \\
\hline$\%$ & 3.18 & 3.27 & 3.26 & 3.09 & 0.117 & 0.55 \\
\hline $\mathrm{kg} / \mathrm{d}$ & 1.05 & 1.03 & 1.09 & 0.91 & 0.066 & 0.054 \\
\hline MUN, mg/dL & 13.0 & 12.9 & 13.0 & 12.5 & 0.85 & 0.97 \\
\hline $\mathrm{SCC}, \times 1,000$ cells $/ \mathrm{mL}$ & 134 & 352 & 173 & 559 & 136.7 & 0.12 \\
\hline
\end{tabular}

${ }_{\mathrm{a}, \mathrm{b}}$ Means within a row with different superscripts differ $(P<0.05)$.

nonconjugated C18:2 flows did not differ between the linseed treatments. However, the cis-9, cis-12-C18:2 flow was higher for the EL treatment compared with the DL treatment, whereas the trans-9,trans-12-C18:2 flow was higher for the DL treatment compared with the other treatments. The DL treatment had a lower total SFA flow compared with the CL treatment, mainly due to the lower C18:0 flow for the DL treatment compared with the other treatments. In contrast, the omasal flow of individual trans-C18:1 isomers was markedly higher for the DL treatment compared with the other linseed treatments. Total and individual cis-C18:1 flows were not affected by the treatments. The flow of trans-10, cis12-C18:2 was higher in the DL treatment compared with the CL and EL treatments, whereas the flow of cis-9,trans-11-C18:2 was not affected. The concentration of DHA was below the detection limit in the CL, EL, and FL treatments. The DL treatment had a small DHA flow $(1.0 \mathrm{~g} / \mathrm{d})$.

\section{Digestibility and Biohydrogenation}

Apparent rumen digestibility of DM, OM, and NDF was not affected by the linseed treatments (Table 7). Whole-tract apparent digestibility of DM was higher for the DL treatment compared with the EL treatment. Whole-tract crude fat digestibility was higher for the FL and DL treatments compared with the EL and CL treatments, whereas the CL treatment also had a higher crude fat digestibility compared with the EL treatment. Whole-tract apparent digestibility of NDF was not affected by the linseed treatments.

Apparent ruminal biohydrogenation of cis-9-C18:1 was not affected by the linseed treatments (Table 8). The EL treatment had a lower apparent ruminal biohydrogenation of cis-9, cis-12-C18:2 compared with the DL treatment, whereas CL and FL treatments had intermediate results. Apparent ruminal biohydrogenation of C18:3n-3 was lower for the EL treatment compared

Table 5. Concentration of ammonia-N, total VFA, and VFA molar proportions in omasal samples of cows fed diets supplemented with crushed linseed (CL), extruded whole linseed (EL), formaldehyde-treated linseed (FL), and docosahexaenoic acid addition to linseed oil (DL)

\begin{tabular}{|c|c|c|c|c|c|c|}
\hline \multirow[b]{2}{*}{ Omasal sample content } & \multicolumn{4}{|c|}{ Dietary treatment } & \multirow[b]{2}{*}{ SEM } & \multirow[b]{2}{*}{$P$-value } \\
\hline & CL & EL & FL & DL & & \\
\hline Ammonia-N, mg/L & 114 & 106 & 129 & 112 & 18.6 & 0.43 \\
\hline Total VFA, $\mathrm{m} M$ & 99 & 101 & 100 & 103 & 3.2 & 0.76 \\
\hline \multicolumn{7}{|c|}{ Molar proportion, $\mathrm{mmol} / \mathrm{mol}$} \\
\hline Acetate & $632^{\mathrm{ab}}$ & $635^{\mathrm{ab}}$ & $640^{\mathrm{a}}$ & $614^{\mathrm{b}}$ & 15.8 & 0.049 \\
\hline Propionate & $216^{\mathrm{ab}}$ & $217^{\mathrm{ab}}$ & $198^{\mathrm{b}}$ & $236^{\mathrm{a}}$ & 17.8 & 0.028 \\
\hline Butyrate & 111 & 110 & 122 & 115 & 4.0 & 0.092 \\
\hline Isobutyrate & 10 & 9 & 9 & 8 & 0.6 & 0.21 \\
\hline Valerate & 14 & 14 & 14 & 13 & 1.0 & 0.55 \\
\hline Isovalerate & $17^{\mathrm{a}}$ & $15^{\mathrm{ab}}$ & $17^{\mathrm{a}}$ & $14^{\mathrm{b}}$ & 0.5 & 0.013 \\
\hline
\end{tabular}

${ }^{\mathrm{a}, \mathrm{b}}$ Means within a row with different superscripts differ $(P<0.05)$. 
Table 6. Nutrient and FA flows into the omasum of cows fed diets supplemented with crushed linseed (CL), extruded whole linseed (EL), formaldehyde-treated linseed (FL), and docosahexaenoic acid addition to linseed oil (DL)

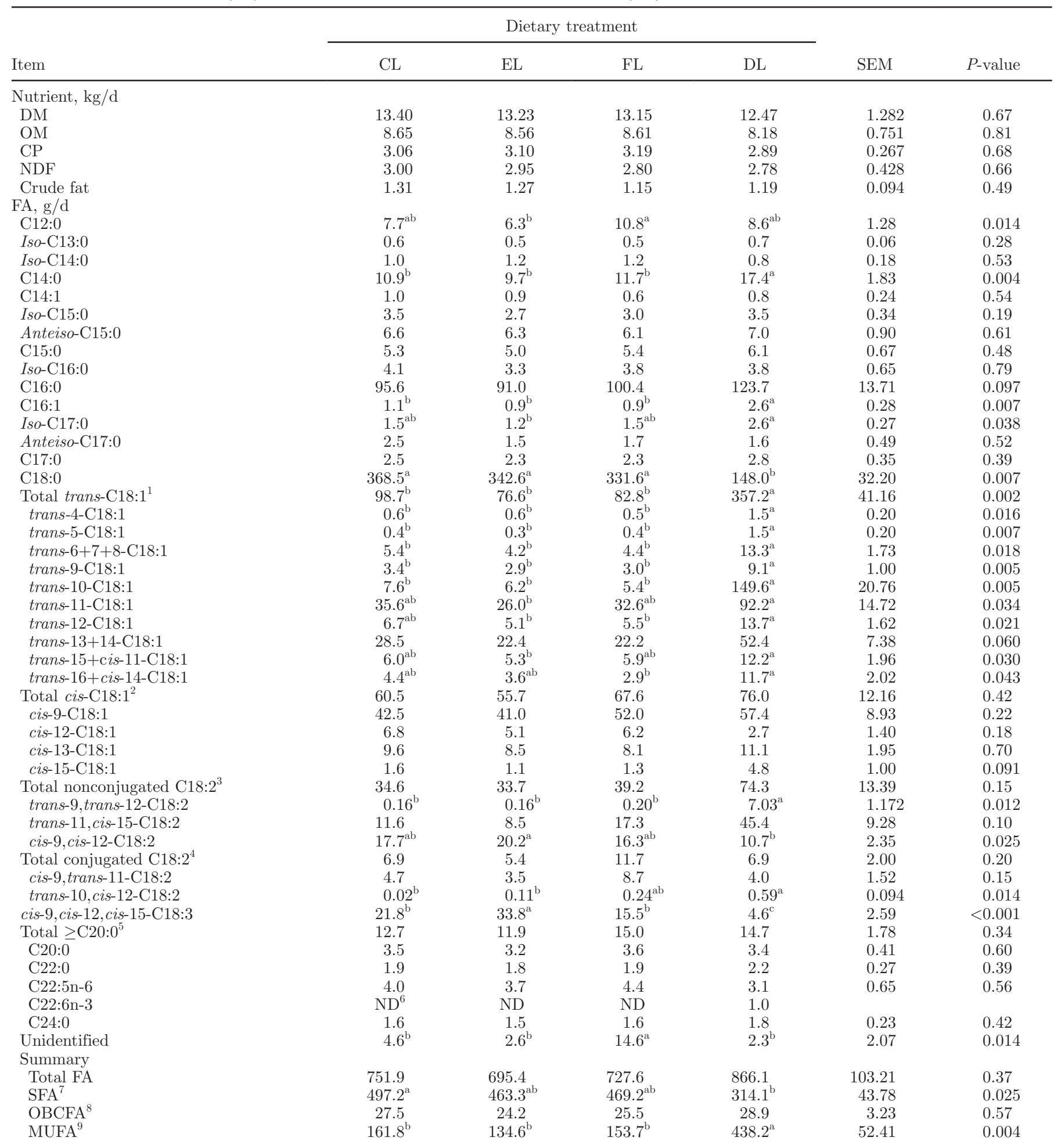


Table 6 (Continued). Nutrient and FA flows into the omasum of cows fed diets supplemented with crushed linseed (CL), extruded whole linseed (EL), formaldehyde-treated linseed (FL), and docosahexaenoic acid addition to linseed oil (DL)

\begin{tabular}{|c|c|c|c|c|c|c|}
\hline \multirow[b]{2}{*}{ Item } & \multicolumn{4}{|c|}{ Dietary treatment } & \multirow[b]{2}{*}{ SEM } & \multirow[b]{2}{*}{$P$-value } \\
\hline & CL & EL & FL & $\mathrm{DL}$ & & \\
\hline $\begin{array}{l}\text { PUFA }^{10} \\
\text { UFA }^{11}\end{array}$ & $\begin{array}{c}68.5 \\
230.3^{\mathrm{b}}\end{array}$ & $\begin{array}{c}78.0 \\
212.6^{\mathrm{b}}\end{array}$ & $\begin{array}{c}72.2 \\
225.9^{\mathrm{b}}\end{array}$ & $\begin{array}{c}91.5 \\
529.7^{\mathrm{a}}\end{array}$ & $\begin{array}{l}17.23 \\
69.09\end{array}$ & $\begin{array}{l}0.72 \\
0.015\end{array}$ \\
\hline
\end{tabular}

${ }^{\mathrm{a}-\mathrm{c}}$ Means within a row with different superscripts differ $(P<0.05)$.

${ }^{1}$ Total trans-C18:1 = $\Sigma($ trans-4-C18:1, trans-5-C18:1, trans-6+7+8-C18:1, trans-9-C18:1, trans-10-C18:1, trans-11-C18:1, trans-12-C18:1, trans-13+14-C18:1, trans-15+cis-11-C18:1, trans-16+cis-14-C18:1).

${ }^{2}$ Total cis-C18:1 = $\Sigma$ (cis-9-C18:1, cis-12-C18:1, cis-13-C18:1, cis-15-C18:1).

${ }^{3}$ Total nonconjugated $\mathrm{C} 18: 2=\Sigma$ (trans-9,trans-12-C18:2, cis-9,trans-13-C18:2, trans-8, cis-13-C18:2, cis-9,trans-12-C18:2, trans-9,cis-12-C18:2, trans-11, cis-15-C18:2, cis-9, cis-12-C18:2, cis-9, cis-15-C18:2).

${ }^{4}$ Total conjugated $\mathrm{C} 18: 2=\Sigma$ (cis-9,trans-11-C18:2, trans-10,cis-12-C18:2, cis-9,cis-11-C18:2+trans-11,cis-13-C18:2, trans-11,trans-13-C18:2, trans-9, trans-11-C18:2+trans-10,trans-12-C18:2).

${ }^{5}$ Total $\geq \mathrm{C} 20: 0=\Sigma(\mathrm{C} 20: 0, \mathrm{C} 20: 1, \mathrm{C} 20: 2, \mathrm{C} 20: 3 \mathrm{n}-3, \mathrm{C} 20: 4 \mathrm{n}-6, \mathrm{C} 22: 0$, cis-13-C22:1, C22:5, C22:6, C24:0).

${ }^{6} \mathrm{ND}=$ not detectable.

${ }^{7}$ Saturated FA $=\Sigma(\mathrm{C} 12: 0, \mathrm{C} 14: 0, \mathrm{C} 15: 0, \mathrm{C} 16: 0, \mathrm{C} 17: 0, \mathrm{C} 18: 0, \mathrm{C} 20: 0, \mathrm{C} 22: 0, \mathrm{C} 24: 0)$.

${ }^{8}$ Odd- and branched-chain FA $=\Sigma($ iso-C13:0, iso-C14:0, iso-C15:0, anteiso-C15:0, C15:0, iso-C16:0, iso-C17:0, anteiso-C17:0, C17:0).

${ }^{9}$ Monounsaturated $\mathrm{FA}=\Sigma(\mathrm{C} 14: 1, \mathrm{C} 16: 1$, total cis-C18:1, total trans-C18:1, C20:1, cis-13-C22:1).

${ }^{10}$ Polyunsaturated $\mathrm{FA}=\Sigma$ (total nonconjugated C18:2, total conjugated C18:2, C18:3n-6, C18:3n-3, C20:2, C20:3n-3, C20:4n-6, C22:5, C22:6).

${ }^{11}$ Unsaturated $\mathrm{FA}=\Sigma(\mathrm{MUFA}, \mathrm{PUFA})$.

with the CL, FL, and DL treatments. In addition, the CL and FL treatments had a lower C18:3n-3 apparent ruminal biohydrogenation compared with the DL treatment.

\section{Plasma TAG FA Composition}

The FL treatment tended to have a higher proportion of C18:3n-3 in plasma TAG compared with the other treatments (Table 9). The DL treatment had lower SFA and higher MUFA compared with the other treatments. The DL treatment had a lower proportion of C18:0, whereas proportions of trans- $6+7+8-\mathrm{C} 18: 1$, trans-10-C18:1, trans-11-C18:1, trans-12-C18:1, and trans-13+14-C18:1 isomers were markedly higher compared with the other treatments. The DL treatment had a higher proportion of PUFA compared with the FL and EL treatments and the FL treatment had a higher proportion of PUFA compared with the CL treatment. This difference was partly caused by the proportion of total nonconjugated C18:2; the DL treatment had a higher proportion of trans-11,cis-15-C18:2 compared with the other treatments, whereas the proportion of cis-9,cis-12-C18:2 was not affected by the different linseed treatments.

\section{Milk FA Composition}

The FL treatment resulted in higher $\mathrm{C} 18: 3 \mathrm{n}-3$ and cis9,cis-12-C18:2 proportions in milk fat compared with the other treatments (Table 10). The DL treatment had a lower C18:0 proportion in milk fat, whereas the pro-

Table 7. Apparent rumen digestibility and apparent whole-tract digestibility of cows fed diets supplemented with crushed linseed (CL), extruded whole linseed (EL), formaldehyde-treated linseed (FL), and docosahexaenoic acid addition to linseed oil (DL)

\begin{tabular}{|c|c|c|c|c|c|c|}
\hline Digestibility & \multicolumn{4}{|c|}{ Dietary treatment } & SEM & $P$-value \\
\hline $\mathrm{OM}$ & 54.9 & 55.9 & 57.2 & 55.7 & 1.51 & 0.41 \\
\hline NDF & 60.1 & 61.0 & 63.6 & 60.6 & 3.78 & 0.44 \\
\hline \multicolumn{7}{|c|}{ Whole-tract apparent digestibility, $\%$} \\
\hline NDF & 67.3 & 68.1 & 68.6 & 68.9 & 2.09 & 0.46 \\
\hline
\end{tabular}

${ }^{\mathrm{a}-c}$ Means within a row with different superscripts differ $(P<0.05)$. 
Table 8. Apparent ruminal biohydrogenation (\%) of cows fed diets supplemented with crushed linseed (CL), extruded whole linseed (EL), formaldehyde-treated linseed (FL), and docosahexaenoic acid addition to linseed oil (DL)

\begin{tabular}{|c|c|c|c|c|c|c|}
\hline \multirow[b]{2}{*}{ Item } & \multicolumn{4}{|c|}{ Dietary treatment } & \multirow[b]{2}{*}{ SEM } & \multirow[b]{2}{*}{$P$-value } \\
\hline & CL & EL & FL & $\mathrm{DL}$ & & \\
\hline cis-9-C18:1 & 77.4 & 78.0 & 73.5 & 65.9 & 3.83 & 0.080 \\
\hline cis-9,cis-12-C18:2 & $92.9^{\mathrm{ab}}$ & $91.9^{\mathrm{b}}$ & $93.7^{\mathrm{ab}}$ & $95.3^{\mathrm{a}}$ & 0.60 & 0.015 \\
\hline cis-9.cis-12,cis-15-C18:3 & $94.0^{\mathrm{b}}$ & $90.9^{\mathrm{c}}$ & $95.4^{\mathrm{b}}$ & $98.5^{\mathrm{a}}$ & 0.49 & $<0.001$ \\
\hline
\end{tabular}

${ }^{\mathrm{a}-\mathrm{c}}$ Means within a row with different superscripts differ $(P<0.05)$.

portions of total trans-C18:1, trans-9,trans-12-C18:2, trans-11,cis-15-C18:2, and cis-9,trans-11-C18:2 were higher compared with the other treatments. The higher proportion of total trans-C18:1 was caused by the higher proportions of trans- $6+7+8-\mathrm{C} 18: 1$, trans-9-C18:1, trans-10-C18:1, trans-11-C18:1, trans-12-C18:1, and trans-13+14-C18:1 isomers for the DL treatment compared with the other treatments. In addition, the DL treatment had higher proportions of cis-13-C18:1 and cis-15-C18:1 isomers compared with the FL treatment, whereas proportions of cis-9-C18:1 and cis-12-C18:1 isomers were lower for the DL treatments compared with the other treatments, respectively the CL treatment.

\section{Transfer Efficiency of C18:3n-3}

Transfer efficiency of C18:3n-3 from intake to milk was higher for the FL treatment compared with the other treatments (Table 11). The FL treatment also resulted in a higher efficiency from omasal C18:3n-3 flow to milk C18:3n-3 yield compared with the other treatments; however, the efficiency was calculated to be $288 \%$.

\section{DISCUSSION}

\section{Fermentation Characteristics}

Inclusion of treated linseed or linseed oil did not affect the rumen fermentation pattern (Doreau et al., 2009a). Indeed, in the present study, no differences in fermentation pattern measured in omasal samples were found between the CL, EL, and FL treatments. The higher propionate and lower acetate proportion for the DL treatment compared with the FL treatment agrees with effects of DHA on rumen fermentation pattern as reported by Fievez et al. $(2003,2007)$ and Vlaeminck et al. (2008). In these studies, supplementing DHA resulted in a decreased rumen concentration of VFA (Fievez et al., 2003, 2007; Boeckaert et al., 2008a; Vlaeminck et al., 2008), an effect which is related to the amount of DHA supplemented (Fievez et al., 2003, 2007). This could explain the absence of a decrease in the omasal concentration of VFA in the current study, as DHA intake $(11.6 \mathrm{~g} / \mathrm{d})$ was lower compared with previous studies (73.1 and $43.7 \mathrm{~g} / \mathrm{d}$; Boeckaert et al., 2008a). Various unsaturated FA have a negative effect on degradation of NDF in the rumen, and fiber degradation is associated with a relatively large acetate-to-propionate ratio (Bannink et al., 2008). In the present experiment, ruminal NDF degradation did not differ between treatments and cannot explain the change in VFA profile observed.

\section{FA Metabolism}

The aim of the present study was to determine the effects of different linseed treatments on FA flows through the gastrointestinal tract and FA profiles in blood plasma and milk fat of lactating dairy cows. The FA proportion in the diet, feed intake, and microbial activity in the rumen may affect the omasal flow of FA. Schmidely et al. (2008) reported a relationship between duodenal FA flow and FA intake, in which proportionally $75 \%$ of ingested FA was recovered in the duodenal FA flow. Higher FA intake than duodenal FA flow was observed for diets containing more than $40 \mathrm{~g}$ of FA/ $\mathrm{kg}$ of DM (Schmidely et al., 2008). Indeed, Jenkins (1993) reported that lipid disappearance from the rumen was more common for diets with added fat than for control diets. A lower recovery of duodenal FA could not be associated to the characteristics of the fat sources in the diet, including the rumen inertness of the fat source (Doreau and Ferlay, 1994). In the current study, the addition of various linseed sources resulted in diets with 44 to $46 \mathrm{~g}$ of $\mathrm{FA} / \mathrm{kg}$ of DM, the recovery of omasal FA was $72.2,75.8,80.9$, and $98.7 \%$ for the EL, FL, CL, and DL diet, respectively. Possible reasons for the lower duodenal or omasal FA flows compared with FA intake are absorption in the rumen, degradation to shorter chains, and underestimation of the flow (Wu et al., 1991). Shingfield et al. (2008) indicated a net synthesis of FA in the rumen on diets with incremental levels of 
Table 9. Fatty acid profile in plasma triacylglycerol of cows fed diets supplemented with crushed linseed (CL), extruded whole linseed (EL), formaldehyde-treated linseed oil (FL), and docosahexaenoic acid addition to linseed oil (DL)

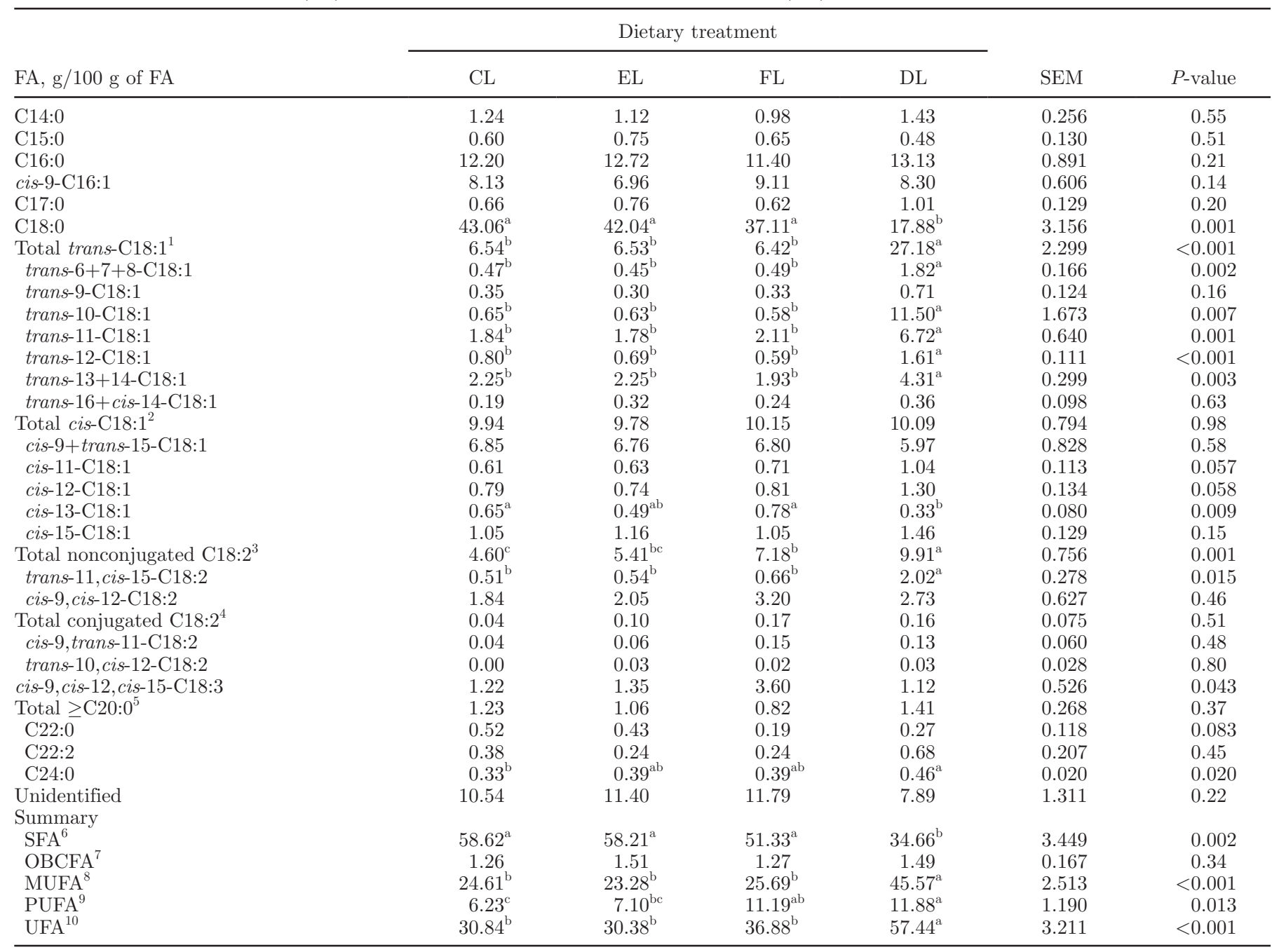

${ }^{\mathrm{a}-\mathrm{c}}$ Means within a row with different superscripts differ $(P<0.05)$.

${ }^{1}$ Total trans-C18:1 = $\Sigma($ trans-4-C18:1, trans-5-C18:1, trans-6+7+8-C18:1, trans-9-C18:1, trans-10-C18:1, trans-11-C18:1, trans-12-C18:1, trans-13+14-C18:1, trans-16+cis-14-C18:1).

${ }^{2}$ Total cis-C18:1 = $\Sigma$ (cis-9+trans-15-C18:1, cis-11-C18:1, cis-12-C18:1, cis-13-C18:1, cis-15-C18:1).

${ }^{3}$ Total nonconjugated C18:2 = $\Sigma$ (trans-9,trans-12-C18:2, cis-9,trans-13-C18:2, trans-8,cis-13-C18:2, cis-9,trans-12-C18:2, trans-9,cis-12-C18:2, trans-11,cis-15-C18:2, cis-9,cis-12-C18:2, cis-9,cis-15-C18:2).

${ }^{4}$ Total conjugated C18:2 $=\Sigma($ cis-9,trans-11-C18:2, trans-10, cis-12-C18:2).

${ }^{5}$ Total $\geq \mathrm{C} 20: 0=\Sigma(\mathrm{C} 20: 0, \mathrm{C} 22: 0, \mathrm{C} 22: 2, \mathrm{C} 24: 0)$.

${ }^{6}$ Saturated FA $=\Sigma(\mathrm{C} 12: 0, \mathrm{C} 14: 0, \mathrm{C} 15: 0, \mathrm{C} 16: 0, \mathrm{C} 17: 0, \mathrm{C} 18: 0, \mathrm{C} 20: 0, \mathrm{C} 22: 0, \mathrm{C} 24: 0)$.

${ }^{7}$ Odd- and branched-chain FA $=\Sigma(\mathrm{C} 15: 0, \mathrm{C} 17: 0)$.

${ }^{8}$ Monounsaturated FA $=\Sigma($ cis-9-C16:1, total cis-C18:1, total trans-C18:1).

${ }^{9}$ Polyunsaturated FA $=\Sigma($ total nonconjugated C18:2, total conjugated C18:2, C18:3n-3, C22:2).

${ }^{10}$ Unsaturated $\mathrm{FA}=\Sigma($ MUFA, PUFA).

sunflower oil. This finding was in agreement with other studies where sunflower oil (Kalscheur et al., 1997; Lock and Garnsworthy, 2002) or soybean oil (Lundy et al., 2004) was fed. Shingfield et al. (2008) concluded that these differences between studies reflect the differences in experimental techniques used to estimate postruminal DM flow and the FA content of feed ingredients and digesta. In the present study, the apparent rumen digestibility of NDF was, on average, $89.9 \%$ of apparent total-tract digestion, indicating a contribution of the hindgut to NDF digestion of some $10 \%$ of the total NDF digestion. This value is well within the 
Table 10. Milk FA profile of cows fed diets supplemented with crushed linseed (CL), extruded whole linseed (EL), formaldehyde-treated linseed oil (FL), and docosahexaenoic acid addition to linseed oil (DL)

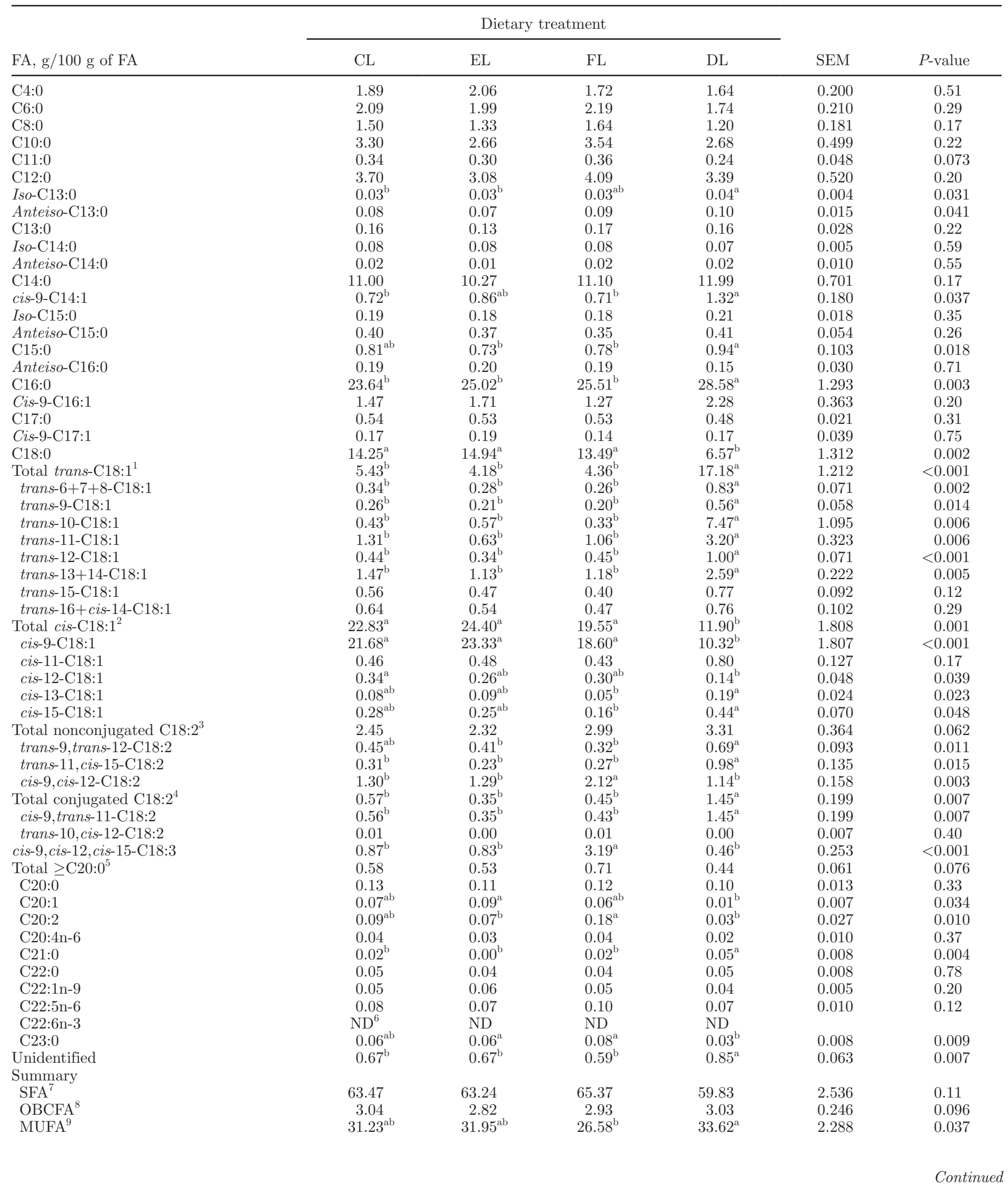


Table 10 (Continued). Milk FA profile of cows fed diets supplemented with crushed linseed (CL), extruded whole linseed (EL), formaldehydetreated linseed oil (FL), and docosahexaenoic acid addition to linseed oil (DL)

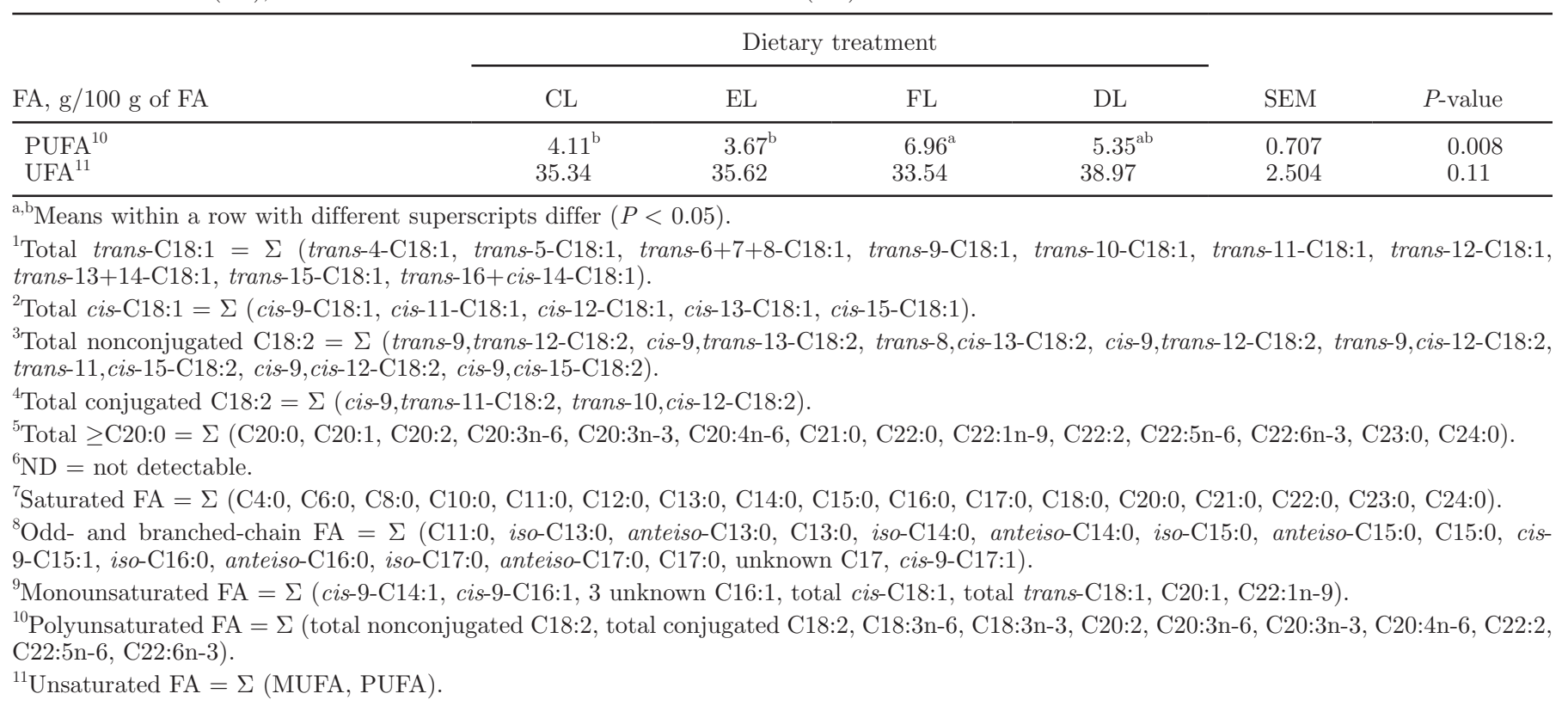

range of values reported in the review of Gressley et al. (2011; range: 3.7 to $23.2 \%$; average: $11.9 \%$ ). These NDF digestibilities obtained with the omasal sampling technique in the present study do not indicate a significant over- or underestimation of NDF flow.

Heat treatment of linseed did not affect the duodenal flow of long-chain FA compared with raw linseed, whereas feeding extruded linseed compared with micronized linseed resulted in a lower C18:3n-3 flow, suggesting higher exposure of the extruded linseed to ruminal bacteria, resulting in higher ruminal biohydrogenation (Gonthier et al., 2004). In the present study, the omasal flow of C18:3n-3 was higher for the EL treatment compared with the other treatments. A numerically higher duodenal flow of C18:3n-3 for extruded compared with rolled linseed was also found by Doreau et al. (2009b). The latter authors concluded that the higher C18:3n-3 flow could be explained by the rapid release of the lipids in the extruded linseed, leading to a higher passage rate. The whole-tract ap- parent digestibility of crude fat was lower for the EL treatment compared with the other treatments in the present study. Sterk et al. (2010) hypothesized that overprotection by the seed coat prevented the C18:3n-3 to be released and absorbed. The lower whole-tract crude fat digestibility indeed suggests that the FA were still captured in the seed coat and might, therefore, not be absorbed. Indeed, a similar C18:3n-3 proportion in plasma TAG and milk fat was found for the EL treatment compared with the CL treatment. Chilliard et al. (2009) compared whole linseed with extruded linseed and reported a higher $\mathrm{C} 18: 3 \mathrm{n}-3$ proportion in milk fat for the cows that received extruded linseed. The researchers suggested that extrusion increases the rate of oil release from the seeds resulting in some protection of the C18:3n-3 against biohydrogenation (Chilliard et al., 2009), or increases the rate of passage to the duodenum (Doreau et al., 2009b). In the present study, whole linseed was extruded but the extrusion process did likely not lead to complete rupture of the seed coat.

Table 11. Transfer efficiency of C18:3n-3 from feed to milk and from omasal flow to milk of cows fed diets supplemented with crushed linseed (CL), extruded whole linseed (EL), formaldehyde-treated linseed oil (FL), and docosahexaenoic acid addition to linseed oil (DL)

\begin{tabular}{lccccrc}
\hline & \multicolumn{9}{c}{ Dietary treatment } & & \multirow{2}{*}{ SEM } & $P$-value \\
\cline { 2 - 5 } Item & $\mathrm{CL}$ & $\mathrm{EL}$ & $\mathrm{FL}$ & $\mathrm{DL}$ & \multicolumn{1}{c}{ SEM } \\
\hline Intake to milk, \% & $3.2^{\mathrm{b}}$ & $3.0^{\mathrm{b}}$ & $13.1^{\mathrm{a}}$ & $1.3^{\mathrm{b}}$ & 0.63 & $<0.001$ \\
Omasal flow to milk, $\%$ & $59.2^{\mathrm{b}}$ & $33.5^{\mathrm{b}}$ & $287.8^{\mathrm{a}}$ & $89.1^{\mathrm{b}}$ & 16.33 & $<0.001$ \\
\hline
\end{tabular}

${ }^{\mathrm{a}, \mathrm{b}}$ Means within a row with different superscripts differ $(P<0.05)$. 
This was confirmed by the higher omasal C18:3n-3 flow, but lower whole-tract crude fat digestibility compared with the other treatments.

Formaldehyde treatment of crushed linseed resulted in a lower calculated effective biohydrogenation in earlier in vitro research (Sterk et al., 2010). However, in the present study, omasal C18:3n-3 flow was lower for the FL treatment compared with the EL treatment, suggesting that formaldehyde treatment was ineffective in protecting linseed oil from ruminal biohydrogenation. The protein of the oilseed should be accessible to formaldehyde to form the rumen-inert formaldehyde-protein matrix, resulting in the effective protection of the FA (Fievez et al., 2007). In the current study, linseed oil was emulsified and encapsulated in a formaldehydetreated casein, which is known to be able to provide an effective protection against biohydrogenation (Ashes et al., 1992). When digesta is sampled from the omasal canal, it is possible that particles with different functional specific gravities segregate as they travel through the sample tube (Ipharraguerre et al., 2007). This could result in an underestimation of the flow of particles of high specific gravity (e.g., corn kernels; Ipharraguerre et al., 2007). The C18:3n-3 flow for the FL treatment might, therefore, be underestimated due to the specific appearance of the product. The physiologically impossible C18:3n-3 transfer efficiency from omasal flow to milk of $288 \%$ also is an indication of underestimation of the omasal C18:3n-3 flow with the FL treatment. The proportion of C18:3n-3 was higher in both plasma TAG and milk fat for the FL treatment compared with the other treatments. Without protection, average C18:3n-3 proportion in milk fat may increase up to $1.2 \%$ of total FA (Glasser et al., 2008), with unsupplemented diets generally containing 0.4 to $0.6 \%$ of total FA (Heck et al., 2009). The proportion of C18:3n-3 in the FL treatment reached $3.19 \%$ of total FA and it is, therefore, concluded that part of the C18:3n-3 from the FL treatment was protected against biohydrogenation.

Boeckaert et al. (2008b) observed increased proportions of biohydrogenation intermediates cis-9,trans-11,cis15-C18:3, trans-11, cis-15-C18:2, cis-9,trans-11-C18:2, trans-10,cis-12-C18:2, cis-9,cis-11-C18:2+trans-11,cis13-C18:2, and all trans-C18:1 isomers in the ruminal digesta of dairy cows receiving $43.7 \mathrm{~g}$ of $\mathrm{DHA} / \mathrm{d}$ in their diet. The increased flow of biohydrogenation intermediates and decreased flow of C18:0 is a clear indication of the inhibitory effect of DHA on ruminal biohydrogenation (Boeckaert et al., 2008b). In the present study, omasal flows of trans-11,cis-15-C18:2 tended to be higher and trans-10,cis-12-C18:2 and total trans-C18:1 were higher for the DL treatment compared with the other linseed treatments. In the present study, a lower level of DHA $(11.6 \mathrm{~g} / \mathrm{d})$ was fed in combination with linseed oil $(420 \mathrm{~g} / \mathrm{d})$, which confirms the effects that DHA has on the ruminal biohydrogenation pathways. In agreement with earlier in vitro research (Sterk et al., 2010), the apparent ruminal biohydrogenation of C18:3n-3 was high, which confirms that the first step of the biohydrogenation pathway is not influenced by the DHA addition. Indeed, the proportion of C18:3n-3 in both milk fat and plasma TAG for the DL treatment was similar compared with the CL and EL treatments. Boeckaert et al. (2008a) reported a DHA proportion in milk fat of $0.28 \mathrm{~g} / 100 \mathrm{~g}$ of FA after feeding $43.7 \mathrm{~g}$ of $\mathrm{DHA} / \mathrm{d}$, but in the current study, DHA could not be detected in plasma TAG or milk fat after feeding $11.6 \mathrm{~g}$ of $\mathrm{DHA} / \mathrm{d}$, due to the lower DHA supply and the high extent of biohydrogenation of DHA (Fievez et al., 2007). In the present study, the lower C18:0 and higher trans-FA proportions in both plasma TAG and milk fat for the DL treatment reflect the inhibition of the biohydrogenation steps from trans-11, cis-15-C18:2 to trans-11-C18:1 and further to C18:0. The proportion of cis-9,trans-11-C18:2 was only higher in milk fat. This FA is not an intermediate in the biohydrogenation of C18:3n-3, but is mainly produced in the mammary gland from trans-11-C18:1. Increased milk fat proportions of trans-10-C18:1, trans-11-C18:1, trans-11,cis-15-C18:2, and cis-9,trans-11-C18:2 after algae supplementation were also reported by Boeckaert et al. (2008a). Both Shingfield et al. (2006) and Boeckaert et al. (2008a) observed a shift from the secretion of trans-11-C18:1 to a relatively greater secretion of trans-10-C18:1. In the present study, a large increase in the proportion of

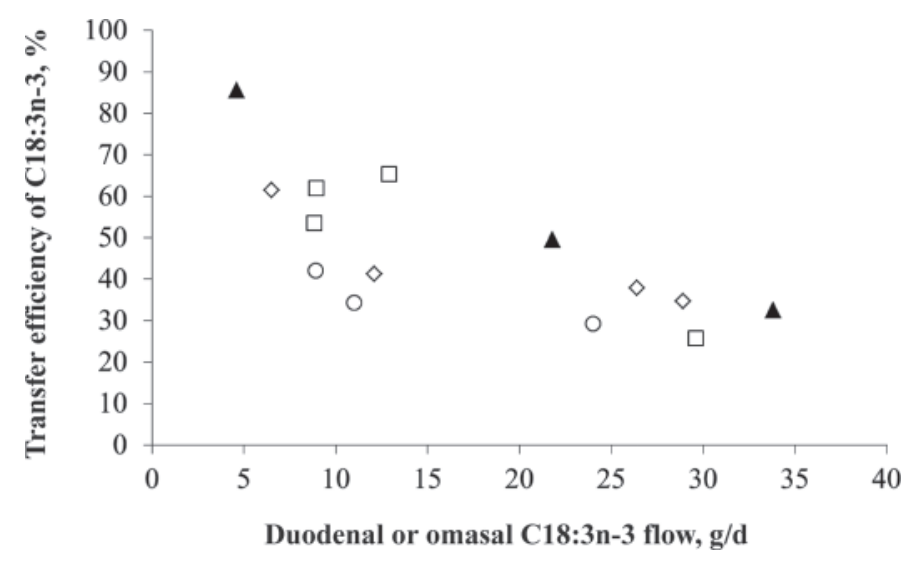

Figure 1. Transfer efficiency from C18:3n-3 flow in the duodenum or omasum to C18:3n-3 in milk. $\diamond$ Gonthier et al. (2004, 2005); $\square$ Loor et al. (2004, 2005a); ○ Loor et al. (2005b,c); $\boldsymbol{\Delta}$ current study [excluding formaldehyde-treated linseed oil (FL)]. Transfer efficiency $=67.9$ $( \pm 6.6)-1.2( \pm 0.3) \times \mathrm{C} 18: 3 \mathrm{n}-3$ flow; $\mathrm{R}^{2}=0.53 ; P=0.003$. 
trans-10-C18:1 also was observed. This might be related to the inclusion of DHA in combination with the linseed oil, resulting in various biohydrogenation intermediates from $\mathrm{C} 18: 3 \mathrm{n}-3$. Cows fed linseed oil in combination with $11.6 \mathrm{~g}$ of DHA/d produced $34 \%$ less milk fat compared with the CL, EL, and FL treatments. Boeckaert et al. (2008a) reported a decrease of $59 \%$ in milk fat yield when feeding $43.7 \mathrm{~g}$ of DHA/d to dairy cows. The decreased milk fat secretion is generally related to the inhibition of de novo FA synthesis in the mammary gland due to increased proportions of various trans-10 FA, in particular trans-10,cis-12-C18:2 (Bauman et al., 2011). The proportion of trans-10,cis-12-C18:2 was significantly increased for the DL treatment in the omasal flow, whereas differences in plasma TAG and milk fat were not detected due to the low proportions found. An intermediate of the trans-10,cis-12-C18:2 pathway is trans-10-C18:1, which is strongly related to milk fat depression in several studies, whereas no regulatory role was demonstrated (Lock et al., 2007). The proportion of trans-10-C18:1 in the present study was significantly higher for the DL treatment in omasal flow, plasma TAG, and milk fat.

\section{Transfer Efficiency}

Transfer efficiencies from C18:3n-3 intake to C18:3n-3 yield in milk for the DL, EL, and CL treatments were largely in line with reported transfer efficiencies for raw linseed $(2.0 \%)$ and extruded linseed $(2.2 \%$; Gonthier et al., 2005), crushed linseed (5.6\%; Sterk et al., 2011), and crude linseed (1.4\%), extruded linseed (1.9\%), and linseed oil (0.5\%; Chilliard et al., 2009). The transfer efficiency for the FL treatment in the current study was significantly higher, confirming the effective protection of C18:3n-3 in this treatment. Chilliard et al. (2000) reported transfer efficiencies from C18:3n-3 infused into the intestine to $\mathrm{C} 18: 3 \mathrm{n}-3$ secreted in milk to range from 35 to $70 \%$. The transfer efficiencies from duodenal or omasal flow of C18:3n-3 to milk yield of C18:3n-3 for the current study and the studies of Gonthier et al. (2004, 2005) and Loor et al. (2004, 2005a,b,c) are presented in Figure 1. As discussed in the previous paragraph, the transfer efficiency for the FL treatment was physiologically impossible, which might be related to an underestimation of the C18:3n-3 flow. The transfer efficiency for the FL treatment was, therefore, excluded from Figure 1. The transfer efficiency ranged from 26 to $86 \%$ and was negatively correlated with the flow of C18:3n-3 in duodenum or omasum $\left(\mathrm{R}^{2}=0.53 ; P<\right.$ 0.01 ; excluding the physiologically impossible recovery for the FL treatment).

\section{CONCLUSIONS}

Feeding EL resulted in a higher omasal C18:3n-3 flow compared with unprotected CL, FL, and DL. However, whole-tract crude fat digestibility was lower for the EL compared with the other linseed sources and this resulted in no difference in $\mathrm{C} 18: 3 \mathrm{n}-3$ proportion in plasma TAG and milk fat compared with the unprotected CL. Feeding FL resulted in higher C18:3n-3 proportions in plasma TAG and milk fat compared with unprotected CL, EL, and DL. The transfer efficiency from C18:3n-3 in feed to C18:3n-3 in milk was much higher for the cows receiving FL. Feeding linseed oil in combination with marine algae rich in DHA resulted in an inhibition of the complete C18:3n-3 biohydrogenation toward C18:0, as indicated by a low omasal C18:0 flow, low C18:0 proportions in plasma TAG and milk fat, and high omasal flows and increased proportions of biohydrogenation intermediates in plasma and milk fat.

\section{ACKNOWLEDGMENTS}

The authors thank the staff of trial farm The Ossekampen, Wageningen University for their assistance in animal care, feeding, and sampling; the laboratory staff of the Animal Nutrition Group, Wageningen University, for their help in chemical analysis; and Tamme Zandstra and Sven Alferink of Wageningen University for their assistance in preparing the linseed treatments. Masters students Steven van der Weerd and Ard van Veen of Wageningen University are gratefully acknowledged for their contribution in the experiment. The financial support of the Food and Nutrition Delta program of SenterNovem (Den Haag, the Netherlands), Royal FrieslandCampina (Amersfoort, the Netherlands), Agrifirm Group (Apeldoorn, the Netherlands), Agrifirm Innovation Center (Apeldoorn, the Netherlands), and Barenbrug Holland B.V. (Oosterhout, the Netherlands) is gratefully acknowledged. Bruno Vlaeminck is a postdoctoral fellow of the Fund for Scientific Research-Flanders (Belgium).

\section{REFERENCES}

Abrahamse, P. A., J. Dijkstra, B. Vlaeminck, and S. Tamminga. 2008a. Frequent allocation of rotationally grazed dairy cows changes grazing behavior and improves productivity. J. Dairy Sci. 91:2033-2045.

Abrahamse, P. A., B. Vlaeminck, S. Tamminga, and J. Dijkstra. $2008 \mathrm{~b}$. The effect of silage and concentrate type on intake behavior, rumen function, and milk production in dairy cows in early and late lactation. J. Dairy Sci. 91:4778-4792.

Ahvenjärvi, S., A. Vanhatalo, P. Huhtanen, and T. Varvikko. 2000. Determination of reticulo-rumen and whole-stomach digestion in lactating cows by omasal canal or duodenal sampling. Br. J. Nutr. 83:67-77. 
Ashes, J. R., P. St. Vincent Welch, S. K. Gulati, T. W. Scott, G. H. Brown, and S. Blakeley. 1992. Manipulation of the fatty acid composition of milk by feeding protected canola seeds. J. Dairy Sci. 75:1090-1096.

AOAC (Association of Official Analytical Chemists). 1990. Official Methods of Analysis of the AOAC. 15th ed. Method no. 905.02. Association of Official Analytical Chemists, Arlington, VA.

Bannink, A., J. France, S. Lopez, W. J. J. Gerrits, E. Kebreab, S. Tamminga, and J. Dijkstra. 2008. Modelling the implications of feeding strategy on rumen fermentation and functioning of the rumen wall. Anim. Feed Sci. Technol. 143:3-26.

Bauman, D. E., K. J. Harvatine, and A. L. Lock. 2011. Nutrigenomics, rumen-derived bioactive fatty acids, and the regulation of milk fat synthesis. Annu. Rev. Nutr. 31:299-319.

Binnerts, W. T., A. T. van't Klooster, and A. M. Frens. 1968. Soluble chromium indicator measured by atomic absorption in digestion experiments. Vet. Rec. 82:470.

Boeckaert, C., B. Vlaeminck, J. Dijkstra, A. Issa-Zacharia, T. Van Nespen, W. Van Straalen, and V. Fievez. 2008a. Effect of dietary starch or micro algae supplementation on rumen fermentation and milk fatty acid composition of dairy cows. J. Dairy Sci. 91:47144727 .

Boeckaert, C., B. Vlaeminck, V. Fievez, L. Maignien, J. Dijkstra, and N. Boon. 2008b. Accumulation of trans $\mathrm{C}_{18 \cdot 1}$ fatty acids in the rumen after dietary algal supplementation is associated with changes in the Butyrivibrio community. Appl. Environ. Microbiol. 74:6923-6930

Brito, A. F., G. A. Broderick, J. J. Olmos Colmenero, and S. M. Reynal. 2007. Effect of feeding formate-treated alfalfa silage or red clover silage on omasal nutrient flow and microbial protein synthesis in lactating dairy cows. J. Dairy Sci. 90:1392-1404.

Chilliard, Y., A. Ferlay, R. M. Mansbridge, and M. Doreau. 2000 Ruminal milk fat plasticity: Nutritional control of saturated, polyunsaturated, trans and conjugated fatty acids. Ann. Zootech. 49:181-205.

Chilliard, Y., F. Glasser, A. Ferlay, L. Bernard, J. Rouel, and M. Doreau. 2007. Diet, rumen biohydrogenation and nutritional quality of cow and goat milk fat. Eur. J. Lipid Sci. Technol. 109:828855

Chilliard, Y., C. Martin, J. Rouel, and M. Doreau. 2009. Milk fatty acids in dairy cows fed whole crude linseed, extruded linseed, or linseed oil, and their relationship with methane output. J. Dairy Sci. 92:5199-5211.

Doreau, M., E. Aurousseau, and C. Martin. 2009a. Effects of linseed lipids fed as rolled seeds, extruded seeds or oil on organic matter and crude protein digestion in cows. Anim. Feed Sci. Technol. 150:187-196.

Doreau, M., and A. Ferlay. 1994. Digestion and utilization of fatty acids by ruminants. Anim. Feed Sci. Technol. 45:379-396.

Doreau, M., S. Laverroux, J. Normand, G. Chesneau, and F. Glasser. 2009b. Effect of linseed fed as rolled seeds, extruded seeds or oil on fatty acid rumen metabolism and intestinal digestibility in cows. Lipids 44:53-62.

Fievez, V., F. Dohme, M. Danneels, K. Raes, and D. Demeyer. 2003 Fish oils as potent rumen methane inhibitors and associated effects on rumen fermentation in vitro and in vivo. Anim. Feed Sci Technol. 104:41-58.

Fievez, V., B. Vlaeminck, T. Jenkins, F. Enjalbert, and M. Doreau 2007. Assessing rumen biohydrogenation and its manipulation in vivo, in vitro and in situ. Eur. J. Lipid Sci. Technol. 109:740-756.

Folch, J., M. Lees, and H. Sloane Stanley. 1957. A simple method for the isolation and purification of total lipids from animal tissues. J. Biol. Chem. 226:497-509.

France, J., and R. C. Siddons. 1986. Determinations of digesta flow by continuous marker infusion. J. Theor. Biol. 121:105-119.

Glasser, F., A. Ferlay, and Y. Chilliard. 2008. Oilseed lipid supplements and fatty acid composition of cow milk: A meta-analysis. J. Dairy Sci. 91:4687-4703.

Gonthier, C., A. F. Mustafa, R. Berthiaume, H. V. Petit, R. Martineau, and D. R. Ouellet. 2004. Feeding micronized and extruded flaxseed to dairy cows: Effects on digestion and ruminal biohydrogenation of long-chain fatty acids. Can. J. Anim. Sci. 84:705-711.

Gonthier, C., A. F. Mustafa, D. R. Ouellet, P. Y. Chouinard, R. Berthiaume, and H. V. Petit. 2005. Feeding micronized and extruded flaxseed to dairy cows: Effects on blood parameters and milk fatty acid composition. J. Dairy Sci. 88:748-756.

Goodridge, J., J. R. Ingalls, and G. H. Crow. 2001. Transfer of omega-3 linolenic acid and linoleic acid to milk fat from flaxseed or Linola protected with formaldehyde. Can. J. Anim. Sci. 81:525-532.

Gressley, T. F., M. B. Hall, and L. E. Armentano. 2011. Ruminant Nutrition Symposium: Productivity, digestion, and health responses to hindgut acidosis in ruminants. J. Anim. Sci. 89:1120-1130.

Heck, J. M., H. J. van Valenberg, J. Dijkstra, and A. C. van Hooijdonk. 2009. Seasonal variation in the Dutch bovine raw milk composition. J. Dairy Sci. 92:4745-4755.

Huhtanen, P., P. G. Brotz, and L. D. Satter. 1997. Omasal sampling technique for assessing fermentative digestion in the forestomach of dairy cows. J. Anim. Sci. 75:1380-1392.

Ipharraguerre, I. R., S. M. Reynal, M. Liñeiro, G. A. Broderick, and J. H. Clark. 2007. A comparison of sampling sites, digesta and microbial markers, and microbial references for assessing the postruminal supply of nutrients in dairy cows. J. Dairy Sci. 90:1904-1919.

Jenkins, T. C. 1993. Lipid metabolism in the rumen. J. Dairy Sci. 76:3851-3863.

Jenkins, T. C., R. J. Wallace, P. J. Moate, and E. E. Mosley. 2008 Recent advances in biohydrogenation of unsaturated fatty acids within the rumen microbial ecosystem. J. Anim. Sci. 86:397-412.

Kalscheur, K. F., B. B. Teter, L. S. Piperova, and R. A. Erdman. 1997 Effect of fat source on duodenal flow of trans- $\mathrm{C}_{18.1}$ fatty acids and milk fat production in dairy cows. J. Dairy Sci. 80:2115-2126.

Khan, N. A., J. W. Cone, and W. H. Hendriks. 2009. Stability of fatty acids in grass and maize silages after exposure to air during the feed out period. Anim. Feed Sci. Technol. 154:183-192.

Khas-Erdene, Q., J. Q. Wang, and D. P. Bu., LWang, J. K., Q. S. Drackley, G. Liu, H. Y. Yang, Wei, and L. Y. Zhou. 2010 Short communication: Responses to increasing amounts of free $\alpha$-linolenic acid infused into the duodenum of lactating dairy cows. J. Dairy Sci. 93:1677-1684

Lock, A. L., and P. C. Garnsworthy. 2002. Independent effects of dietary linoleic and linolenic fatty acids on the conjugated linoleic acid content of cows' milk. Anim. Sci. 74:163-176.

Lock, A. L., C. Tyburczy, D. A. Dwyer, K. J. Harvatine, F. Destaillats, Z. Mouloungui, L. Candy, and D. E. Bauman. 2007. Trans-10 octadecenoic acid does not reduce milk fat synthesis in dairy cows. J. Nutr. 137:71-76.

Loor, J. J., A. Ferlay, A. Ollier, and Y. Chilliard. 2005a. Relationship among trans and conjugated fatty acids and bovine milk fat yield due to dietary concentrate and linseed oil. J. Dairy Sci. $88: 726-740$.

Loor, J. J., A. Ferlay, A. Ollier, K. Ueda, M. Doreau, and Y. Chilliard 2005b. High-concentrate diets and polyunsaturated oils alter trans and conjugated isomers in bovine rumen, blood and milk. J. Dairy Sci. 88:3986-3999

Loor, J. J., K. Ueda, A. Ferlay, Y. Chilliard, and M. Doreau. 2004 Biohydrogenation, duodenal flow, and intestinal digestibility of trans fatty acids and conjugated linoleic acids in response to dietary forage: Concentrate ratio and linseed oil in dairy cows. J. Dairy Sci. 87:2472-2485.

Loor, J. J., K. Ueda, A. Ferlay, Y. Chilliard, and M. Doreau. 2005c Intestinal flow and digestibility of trans fatty acids and conjugated linoleic acids (CLA) in dairy cows fed a high-concentrate diet supplemented with fish oil, linseed oil, or sunflower oil. Anim. Feed Sci. Technol. 119:203-225.

Lundy, F. P., III, E. Block, W. C. Bridges Jr., J. A. Bertrand, and T. C. Jenkins. 2004. Ruminal biohydrogenation in Holstein cows fed soybean fatty acids as amides or calcium salts. J. Dairy Sci. $87: 1038-1046$

Petit, H. V., R. J. Dewhurst, N. D. Scollan, J. G. Proulx, K. Khalid, W. Haresign, H. Twagiramungu, and G. E. Mann. 2002. Milk production and composition, ovarian function and prostaglandin secretion of dairy cows fed omega-3 fats. J. Dairy Sci. 85:889-899. 
Schmidely, P., F. Glasser, M. Doreau, and D. Sauvant. 2008. Digestion of fatty acids in ruminants: A meta-analysis of flows and variation factors. 1. Total fatty acids. Animal 2:677-690.

Shingfield, K. J., S. Ahvenjärvi, V. Toivonen, A. Vanhatalo, P. Huhtanen, and J. M. Griinari. 2008. Effect of incremental levels of sunflower-seed oil in the diet on ruminal lipid metabolism in lactating cows. Br. J. Nutr. 99:971-983.

Shingfield, K. J., C. K. Reynolds, G. Hervás, J. M. Griinari, A. S. Grandison, and D. E. Beever. 2006. Examination of the persistency of milk fatty acid composition responses to fish oil and sunflower oil in the diet of dairy cows. J. Dairy Sci. 89:714-732.

Sterk, A., R. Hovenier, B. Vlaeminck, A. M. van Vuuren, W. H. Hendriks, and J. Dijkstra. 2010. Effects of chemically or technologically treated linseed products and docosahexaenoic acid addition to linseed oil on biohydrogenation of C18:3n-3 in vitro. J. Dairy Sci. 93:5286-5299.

Sterk, A., B. E. O. Johansson, H. Z. H. Taweel, M. Murphy, A. M. van Vuuren, W. H. Hendriks, and J. Dijkstra. 2011. Effects of forage type, forage to concentrate ratio, and crushed linseed supplementation on milk fatty acid profile in lactating dairy cows. J. Dairy Sci. 94:6078-6091.

Tamminga, S., W. M. Van Straalen, A. P. J. Subnel, R. G. M. Meijer, A. Steg, C. J. G. Wever, and M. C. Blok. 1994. The Dutch protein evaluation system: The DVE/OEB-system. Livest. Prod. Sci. 40:139-155.

Taweel, H. Z., B. M. Tas, H. J. Smit, A. Elgersma, J. Dijkstra, and S. Tamminga. 2005. Effects of feeding perennial ryegrass with an elevated concentration of water-soluble carbohydrates on intake, rumen function and performance of dairy cows. Anim. Feed Sci. Technol. 121:243-256.

Van Es, A. J. H. 1975. Feed evaluation for dairy cows. Livest. Prod. Sci. 2:95-107.

van Zijderveld, S. M., B. Fonken, J. Dijkstra, W. J. J. Gerrits, H. B. Perdok, W. Fokkink, and J. R. Newbold. 2011. Effects of a combination of feed additives on methane production, diet digestibility, and animal performance in lactating dairy cows. J. Dairy Sci. 94:1445-1454.

Vlaeminck, B., G. Mengistu, V. Fievez, L. de Jonge, and J. Dijkstra. 2008. Effect of in vitro docosahexaenoic acid supplementation to marine algae-adapted and unadapted rumen inoculum on the biohydrogenation of unsaturated fatty acids in freeze-dried grass. J. Dairy Sci. 91:1122-1132.

Wu, Z., O. A. Ohajuruka, and D. L. Palmquist. 1991. Ruminal synthesis, biohydrogenation, and digestibility of fatty acids by dairy cows. J. Dairy Sci. 74:3025-3034. 